\title{
Does Underwriter Reputation Promote Fair Pricing Behavior In The IPO Process? - Evidence From ChiNext-Listed Firms
}

\author{
Zuguang Wu, Xi'an Jiaotong University/Xi'an University of Technology, China \\ Difang Wan, Xi'an Jiaotong University, China
}

\begin{abstract}
Motivated by the observation of three long-existing phenomena in the ChiNext market - which are high issuing prices, high price-earnings ratios, and strikingly high capital raised in IPOs - this study empirically examines whether underwriters reflect fair attitudes toward, and treatment of, different stakeholders through accurate pricing and whether the attitude varies with different underwriter reputations. We do this by investigating whether the extent of underpricing is significantly reduced by underwriter reputation. We find that the role of underwriter reputation as a mechanism of disciplining opportunistic behavior and as a third-party certification is muted. Although underwriter reputation is still highly correlated with offering price, underwriter reputation doesn't lower underpricing effectively. Underwriters simply take advantage of their reputation for their selfish interests, which unethically damages stock investment returns, especially for the small and middle shareholders. We conclude that underwriters do not exhibit good business ethics to promote fair pricing in ChiNext IPOs.
\end{abstract}

Keywords: Ethics; Underwriter Reputation; Intrinsic Value; Under-Pricing; Information Asymmetry

\section{INTRODUCTION}

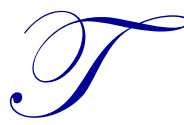

he ChiNext, meaning China's future, was launched in October 2009 in China, mainly for the purpose of financing growth enterprises. Since its launch, the market has shown the three-high phenomenon, which includes high issuing price, high price-earnings ratio, and high proceeds raised. ChiNext listed companies are typically small in scale, have a large proportion of intangible assets, and have the potential to grow quickly. These companies are usually riskier than well-established large firms and therefore investors in the ChiNext market demand higher returns than in the senior equity market. While the price-earnings ratio is high, it is not uncommon for share prices to drop below issuing price in the ChiNext market. Specifically, up to May 26, 2010, about $20 \%$ or seventeen out of 86 stocks listed in the market closed below the issuing price. Coupled with this observation is the fact that underpricing is extremely high and the overall market underpricing rate reaches 0.6 in the ChiNext market. It is surprising that breaking the issuing price and a large extent of underpricing can co-exist so soon after the market was launched. What is the story behind the seemingly paradoxical phenomenon? As we know, to have an interesting IPO, the investment bankers have to tell a story. They sell the bright future of the company with a brilliant business plan, anticipating the future cash-flows in their price-setting (Fassin, 2000). Do underwriters tell the story appropriately or do they cheat through abusing their power, that is, do they work well on IPOs and price the shares correctly? The main function of underwriters in IPOs is to reduce financing costs and ensure a successful issuance through their third party certification function; by easing asymmetry of information between insiders and outsiders about the quality of the IPO companies, they should improve pricing efficiency and optimize resource allocation. This embodies "relative success in fulfilling the expectations of multiple stakeholders" (Fombrun \& Shanley, 1990). Beatty and Ritter (1986) show that investment banks, to survive in the industry, should price closely enough to the correct level. Underpricing too much leads to the loss of investors, and overpricing too much causes the loss of issuers. Pricing correctly is one of an underwriter's basic objectives and it reflects inherent business ethics and service quality. Intuitively, a reputable underwriter should carefully maintain its reputation by 
providing ethical service to issuers and investors in order to boost its business. Naturally, underwriter reputation should constrain opportunistic behavior, which destroys their reputation. The most important part of high quality and ethical service is to price the securities according to their intrinsic value. Previous studies have drawn the conclusion that a higher underwriter reputation leads to a lower level of under-pricing. The underwriter reputation mechanism does work in alleviating opportunistic behavior and reducing the information asymmetry (McDonald \& Fisher, 1972; Tinic, 1988; Dunbar, 2000). However, the observation in the ChiNext market raised the following question: Does the coexistence of high under-pricing and serious breaking of issuing price in the ChiNext market indicate that underwriters violate their basic business ethics and malfunction in the pricing process?

In this paper, we systematically investigate the problem of whether underwriters function as well as a service provider to several types of stakeholders in the ChiNext market, or violate their basic business ethics to price off line for their own interests. First, we find a significant difference between IPO prices in the ChiNext market and intrinsic stock value estimated by the residual income valuation model. Second, we do not find significant relationships between underwriter reputation and the degree of under-pricing, indicating that the underwriter reputation mechanism does not play an obvious role in mitigating the information asymmetry problem and advancing pricing efficiency in the ChiNext market. Third, by examining both the relationship between underwriter reputation and offering price, and the relationship between underwriter reputation and underwriting expenses, we find that higher underwriter reputation is associated with higher offering price and greater underwriting fees. The empirical results indicate that underwriters make great gains in their own interests through raising the offer price and conducting opportunistic behavior. Underwriting malfunctions in the pricing process and the underwriter reputation mechanism does not work effectively. Finally, we investigate the relationship between underwriter reputation and over-raised proceeds and find that the higher the underwriter reputation, the higher the over-raised proceed. The empirical results show that opportunistic behavior meets the interests of both issuer and underwriter. An issuer accepts the fact that offering price must be high enough and thus the issuer raises funds for more than it is worth. High under-pricing harms the interests of the small shareholders, who can only trade in secondary markets, so it reflects unfair behavior against different stakeholders (Freeman, 1984) due to conflicts of interest (Crane \& Matten, 2004).

All the findings show that underwriters have not exhibited their business ethics well in the ChiNext IPO market. Most unethical corporate behaviors, fortunately, do not have the magnitude of the scandals seen in the press, but they exist in a range of forms (Fassin, 2005). Financial intermediaries, such as underwriters, will always be confronted by difficult choices, with ethical dilemmas such as whether to fulfill their ethical duty or grab private benefits under information asymmetry.

\section{LITERATURE REVIEW AND HYPOTHESIS DEVELOPMENT}

\subsection{Underwriter Reputation and IPO Under-Pricing}

Under information asymmetry, investors cannot effectively identify the quality of IPO firms or their projects. This will lead to adverse selection behavior and eventually the market will become a lemon market. In order to solve the problem of asymmetric information and avoid IPO market failure, there must be trustworthy third parties to deliver valuable information to investors. Underwriters, as financial intermediaries in the IPO market, have information advantages over investors in regard to IPO firms. In addition, underwriters are also information producers themselves and they can provide investors with valuable information about valuation by carrying out due diligence.

Chemmanur and Fulghieri (1994) have modeled how an investment bank builds up its reputation based on IPO history and predicts that the extent of under-pricing is negatively correlated with underwriter reputation. The vast majority of empirical studies have shown that the underwriters, as financial intermediaries, can play the role of third-party certification to produce valuable information and mitigate the information asymmetry between investors and issuers. The higher the underwriter reputation is, the lower the underpricing. High underwriter reputation can reduce under-pricing by improving pricing accuracy in raising enough funds for the issuer (McDonald \& Fisher, 1972; Tinic, 1988; Dunbar, 2000). Benveniste et al. (2002) argue that the IPO pricing information created by underwriters will become public goods, and that there exist information spillovers. Information spillovers will 
mitigate the information asymmetry, which will be effective in reducing IPO underpricing. However, Chemmanur and Fulghieri's (1994) conclusion is based on two critical assumptions. The first one is that an underwriter's fraudulent behavior damages its reputation capital, and the other is that the income of an underwriter is determined by its reputation. Those two assumptions do not apply universally. As a rational economic agent, an underwriter may behave opportunistically when facing a different institutional environment. For that reason, underwriter reputation and IPO pricing exhibit different relationships under various scenarios. For example, Kirkulak and Davis (2005) found that the relationship between underwriter reputation and IPO underpricing is positive when the demand for new shares is large, but this relationship is negative when the demand is low. Guo and Zhao (2006) found that underwriter reputation and IPO under-pricing are not correlated after controlling for price-earnings ratio.

In China, the securities market is still far from well-established and it may not fully meet the above two conditions. First, the underwriter service fee is a fraction of the proceeds raised on IPO in China. So, in the Chinese IPO process, the income of underwriters is closely related to the issue price rather than directly to reputation. The higher issue price, naturally, earns the underwriter a higher service fee. Specifically, from January 1, 2005 onward, issuers and their underwriters are required to determine the offering price through a process of price inquiries to inquiry targets. The price inquiry process includes two phases, which are the initial inquiry and the accumulated bidding inquiry. The initial inquiry determines the stock price range, and the accumulated bidding inquiry fixes the issuing price. Issuer and underwriter select certain inquiry objects to make an initial inquiry. During the initial inquiry phase, underwriters provide an investment value analysis report, which gives the valuation range to the inquiry objects, in order to determine the stock price range. During the second phase, accumulated bidding inquiry is directed to all the inquiry objects. The issuer and the underwriter determine the issue price in consultation, based on the subscription condition of the inquiry object and other factors (such as the company's fundamentals, future growth, etc.). They also determine the subscription list and the effective net purchase of shares offline at the same time. An initial inquiry object cannot participate in online distribution. It can be seen that the underwriter plays an important role in determining the offering price by providing value analysis reports to the inquiry objects and by selecting initial inquiry objects in the first phase and by fixing the price, utilizing other factors, in the second phase. The institutional set-up provides some room for an underwriter to manipulate the issuing price to seek his own benefit. The underwriter may demonstrate opportunistic behavior, which makes the issue price deviate upward from its intrinsic value. Second, the underwriter reputation system is not perfect in China. There isn't an authoritative underwriter reputation ranking system. Two influential underwriter ranking systems are the business performance rankings, published annually by the Securities Association of China, and the business magnitude of value rank, issued by the Shanghai Wei Hai investment brokerage consulting firm. Both of these are ranked according to the amount of underwriting; that is, an existing reputation mechanism does not directly connect the price performance of an IPO to the underwriter's reputation. Neither a short-term breaking issue price, nor a long-term market price deviating from the issuing price, directly damages an underwriter's reputation. So, the underwriter reputation mechanism can't effectively constrain their pricing behavior in China. Therefore, both assumptions in Chemmanur and Fulghieri's (1994) theoretical reputation model are violated. As a result, pricing efficiency is not important to underwriters, and they have a strong incentive to engage in opportunistic behavior to improve their revenue but not their reputation. Additionally, inquiry investors face the situation where the highest bidder gets the advantage. In the context of high underpricing and overvalued stock, the inquiry investors obtain profit from the spread between the second market exchange price and the issuing price. So, it is the dominant choice for inquiry investors to take the high price bid strategy, thus acting in concert with the underwriter opportunistic behavior.

Overall, IPO efficiency depends on the result of three parties' games among issuers, underwriters, and inquiry investors. In the context where the reputation mechanism is not yet perfect, underwriters' opportunistic behavior results in issuing prices deviating further upward from the intrinsic value. Issuers and inquiry investors are willing to accept this result. That is, there is opportunistic behavior among underwriters, issuers and inquiry investors, acting in concert with the underwriter due to their selfish motives, and the coordinated behavior is mainly a high-price strategy to fight for placement share. The result of the collusion is that reputation can't constrain the underwriter to reduce the IPO underpricing. Underwriters malfunction in their role of third-party certification, which otherwise should reduce market information asymmetry. 
Therefore, we propose the hypothesis:

H1: Underwriter reputation does not work effectively to improve pricing accuracy and promote fair securities trading on IPOs, and thus there will be no significant correlation between underwriter reputation and underpricing.

\subsection{Issue Price and Underwriter Reputation}

Underwriters do not function well in reducing the extent of underpricing. That is, underwriters violate their basic business values. Why is that? Opportunistic behaviors of underwriters create more revenue for IPO issuers and underwriters themselves. The revenue from each IPO is determined primarily by issue size. Under information asymmetry, investors can verify the quality of the issuer only in an imperfect and costly manner. The information provided by an underwriter provides an important reference for investors. If the underwriter has a great performance history, its information can have a significant influence on investment decisions. So, the higher the underwriter reputation is, the higher the investor confidence level and the higher the issue price. Also, the issuer compensates the underwriter more for its loss of reputation capital. Therefore, the underwriters opportunistically take advantage of their reputation to push up the offering price and earn more underwriting fees.

Thus, we put forward our hypotheses:

H2: Underwriters price upward by abusing their power, which is associated with their reputation. So, the issue price will be positively associated with the underwriter's reputation.

H3: Underwriters can gain benefits from their reputation by pushing up the offering price, and thus the underwriting fees will be positively associated with the underwriter's reputation.

\section{EMPIRICAL METHODOLOGIES}

\subsection{Sample}

Our sample consists of the ChiNext publicly listed companies in Shenzhen during the period from October 30, 2009 to May 20, 2010. The total number of firm-year observations is 82. There are three compelling reasons for the choice of the ChiNext publicly listed firms as a topic of study. Primarily, the ChiNext IPO market has the obvious phenomenon of three-high, and we determine whether or not underwriters function well by investigating the reasons behind the three-high phenomenon. Furthermore, market-oriented reforms for IPOs launched in June 2009. The reform has accelerated the process of marketization by decreasing administrative intervention. The ChiNext board was launched after the market-oriented reforms. We need to know whether or not underwriters play the role of third-party certification in an environment with a higher degree of market features. Moreover, one entrepreneurial field with numerous unethical practices in recent years is the start-up sector. Ethical issues are involved in the different steps of the start-up process for innovative companies (Fassin, 2000). In particular, the exercise of raising funds and the final step, listing on the stock exchange, lead to enormous conflicts of interest (Fassin, 2005).

\subsection{Data on Underwriter Reputation}

We measure underwriter reputation according to the ranking system of the Securities Association of China. The volume of all IPOs underwritten by each investment bank on all Chinese securities and debt markets and the volume ranking of each investment bank are available on the website of the Securities Association of China. Each year, we define underwriter reputation (REP) using the market share rank of total underwriting activity, measured in Yuan, by the underwriter over the prior three-year rolling window, following Megginson and Weiss (1991). The larger the total underwriting amount, the higher the underwriter reputation is ranked, and the smaller the value of $R E P$ is. For example, if an underwriter is ranked as the most reputable among all investment banks, $R E P$ is equal to the smallest number among all rankings. We think this measure accurately captures underwriter reputation, since reputation is primarily built on past success. 


\subsection{Data on IPO in ChiNext Market}

The market and company data mainly come from the Chinese Stock Market and Accounting Research (CSMAR) database. In addition, the over-raised funds data are collected manually from the listed company announcement files. The data of future earnings per share missing from the major data sources are added according to the Guangda Securities System.

Based on these data, we constructed the following variables for our formal statistical analysis. First, the underpricing level, $I R$, is defined as $(P-O P) / O P$, where $O P$ denotes the offering price and $P$ denotes the closing price on the first trading day. Second, the market-adjusted underpricing level, $A R$, as a control for the macroeconomic impact on growth firms, equals $(P-O P) / O P-\left(M_{1}-M_{0}\right) / M_{0}$, where $M_{0}$ and $M_{1}$, respectively, denote the closing index values on the offering day and the first trading day of the Small and Medium Board of the Shenzhen Stock Exchange. The first-day share turnover, TO, is measured by the ratio of the turnover of stocks, TS to the circulation of capital, and TRS on the first trading day. The Illiquidity ratio variable, ILIQ, is defined as $|r| / v o l$, where $|r|$ denotes the absolute value of stock return on the first trading day and $v o l$ is the turnover (Unit: one billion Yuan) on the first trading day. The outstanding shares variable, $L S P$, is derived from $L S \times O P$, where $L S$ denotes the number of outstanding shares. The success rate, $L W R$, is equal to the effective amount of purchase, divided by the circulation. The underwriting expense ratio, FER, equals the total underwriting fee divided by the total underwriting amount. The market index of issue date, MKI, is the Small and Medium Board index of Shenzhen, which represents the market sentiment. The subscription ratio off-line, $M K H$, is the effective purchase amount, scaled by the total placement; it represents the market demand level of the primary market. The issue size, SIZE, is the total number of shares issued by the IPO firm. Lastly, the firm age, YEAR, measures how many years have passed from when it was set up until the IPO year.

\subsection{Data on Residual Income and Residual Income Valuation Model}

Book value and the predicted earnings per share all come from the Chinese Stock Market and Accounting Research (CSMAR) database. The dividends data and future earnings per share are all provided by the Guangda Securities System. According to the residual income valuation model (Lee et al., 1999), we are able to calculate the intrinsic value of stock $V$, which equals $V_{t}=B_{t}+\frac{\left(F R O E_{t+1}-r_{e}\right)}{\left(1+r_{e}\right)} B_{t}+\frac{\left(F R O E_{t+2}-r_{e}\right)}{\left(1+r_{e}\right)^{2}} B_{t+1}+T V$, where $F R O E_{t+i}=F E P S_{t+i} / B_{t+i-1}$, $T V=\frac{\left(F R O E_{t+3}-r_{e}\right)}{\left(1+r_{e}\right)^{2} r_{e}} B_{t+2}, T=3, B_{t+i}=B_{t+i-1}+F E P S_{t+i}-F D P S_{t+i}$, and $F D P S_{t+i}=F E P S_{t+i} \times k . B_{t}$ represents book value per share of $\mathrm{t}$ year. $F E P S_{t+i}$ represents the predicted earnings per share of $t+i$ year. We use the mean of analyst forecast as the predicted earnings per share. $F D P S_{t+i}$ denotes the predicted dividends per share of $t+i$ year, which is equal to $F E P S_{t+i}$ times the payment ratio ${ }^{k}$. FROE $E_{t+1}$ denotes the predicted equity return ratio of $t+1$ year. $T V$ represents the

final value. $r_{e}$ denotes the estimated capital cost. Because the ChiNext was launched only a short time ago, the listed companies cannot have the market risk premium rate of return available. So, capital cost is simplified as the risk-free interest rate. Specifically, we use the three-year treasury bond rate to measure the risk-free rate. 


\section{EMPIRICAL RESULTS}

\subsection{Descriptive Statistics}

Table 1 presents descriptive statistics on the variables used in the analysis.

Table 1: Descriptive Statistics on the Variables used in the Analysis

\begin{tabular}{lccccc}
\hline \multicolumn{1}{c}{ Variables } & Mean & Median & Std. Dev & Min & Max \\
\hline Issue Price & 33.604 & 28.995 & 17.241 & 11.300 & 88.000 \\
Price-earnings ratio & 68.983 & 65.510 & 19.556 & 36.000 & 126.670 \\
Under-pricing rate & 0.598 & 0.475 & 0.444 & -0.099 & 2.097 \\
Adjusted under-pricing rate & 0.580 & 0.477 & 0.425 & 0.001 & 2.065 \\
Issue size (million shares) & 22.272 & 19.500 & 9.992 & 10.000 & 62.000 \\
Net assets per share before IPO & 2.729 & 2.550 & 0.968 & 1.270 & 6.550 \\
Net assets per share after IPO & 9.913 & 8.660 & 4.648 & 4.100 & 25.130 \\
Underwriter ranking & 21 & 15 & 17.454 & 1 & 73 \\
Underwriting expense ratio & 0.051 & 0.050 & 0.018 & 0.017 & 0.100 \\
\hline
\end{tabular}

Table 1 reveals some characteristics of IPOs in the ChiNext market. First, the average number of shares issued is about 22.27 million and the average issue price is 33.6 Yuan in the ChiNext market. Second, the priceearnings ratio is 69 on average and the mean over-raise multiple reaches 131.360. The mean adjusted under-pricing ratio of 0.58 is much higher than the ratio on the mainboard market, which is equal to 0.45. Compared to the observation about the mainboard market, the three-high phenomenon is obvious (Wang et al., 2006). After IPO, the net assets per share, which benefit from the high offering, price soared from 2.7 Yuan from the date of issue to 9.9 Yuan after issue. Third, the mean underwriter ranking is 21 , which indicates that issuers tend to choose the underwriting service provided by a more reputable underwriter. Fourth, the average rate of underwriting fees is 0.051 , which implies that the underwriting expenses reach more than 5\%. However, the maximum underwriting fee rate is $10 \%$, but the minimum underwriting fee rate is only $1.7 \%$. This indicates that there exists a big gap between the underwriting fee rates.

\subsection{Does Issuing Price Systematically Distort Stock Intrinsic Value Upward?}

We calculate the ChiNext IPO stock intrinsic value by employing the residual income valuation model, and comparing the issue price and the intrinsic equity value using both $t$ test and sign rank test. The test result shows the $\mathrm{t}$ value is $3.289^{* * *}(\mathrm{p}=0.0015)$ and the $\mathrm{Z}$ value is $2.938^{* * *}(\mathrm{p}=0.0033)$, indicating that there is a significant difference between the issue price and the corresponding intrinsic equity value in the ChiNext IPOs. Issue price evidently turns upward, away from intrinsic value. It's worth noting that when we calculate the stock intrinsic value, we do not adjust the capital cost according to the market risk premium rate of return. But if the market risk premium is taken into account, the intrinsic value according to the residual income pricing model will be smaller and then the deviation of issue price from intrinsic value will be even greater. So, the empirical result implies that the underwriter prices the offering price upward systematically, and our preliminary evidence shows that underwriters do not perform their basic task well.

\subsection{Underwriter Reputation and ChiNext IPOs}

Table 2 reports the primary regression results. In order to verify the robustness of the results, we adopt different dependent variables, such as the under-pricing rate (IR) and the adjusted under-pricing rate (AR), etc., to support our argument. The control variables introduced in the regression come from relevant literature, such as Kirkulak and Davis (2005), Carter et al., (1998), Beatty et al., (1998) and Song (2004). We apply logarithms to the variables in the model, and then the distributions of the variables are normalized and the effect of the outliers reduced.

The regression results of several models are presented in Table 2. The maximum value of the variance inflation factor (VIF) is 3.49, which is less than 10, indicating that multicollinearity is unlikely. Model 1 and Model 2 provide the result of the regressions with the underpricing rate (IR) and with the market-adjusted underpricing rate 
(AR) as dependent variables, respectively. As anticipated, the coefficients for underwriter reputation are not significant for the two univariate regressions. The empirical results do not depend on how the dependent variables are measured, that is, whether the dependent variable is defined as the under-pricing rate (IR) or the adjusted underpricing rate (AR). We find that underwriter ranking (REP) is not significantly correlated to the underpricing rate $(\mathrm{t}=$ $0.021, \mathrm{p}=0.7200)$ or market-adjusted underpricing rate $(\mathrm{t}=0.300, \mathrm{p}=0.7620)$, which indicates that underwriter reputation does not work in reducing the gap between the issuing price and the intrinsic stock value. That is, underwriter reputation malfunctions in improving the pricing efficiency and ultimately promoting a fair market trading order. For investors, underwriter pricing does not convey effective information about the intrinsic value of the stock, whether the underwriter reputation is high or low. So, underwriter reputation is useless in mitigating the information asymmetry during the IPO process. The empirical result supports hypothesis 1 .

Table 2: Underwriter Reputation and ChiNext IPOs

\begin{tabular}{|c|c|c|c|c|c|}
\hline \multirow{3}{*}{$\begin{array}{c}\text { Independent } \\
\text { Variables }\end{array}$} & \multicolumn{5}{|c|}{ Dependent Variables } \\
\hline & $I R$ & $A R$ & $O P$ & $F E R$ & $F E E$ \\
\hline & Model 1 & Model 2 & Model 3 & Model 4 & Model 5 \\
\hline$R E P$ & $\begin{array}{l}0.021 \\
(0.36)\end{array}$ & $\begin{array}{l}0.019 \\
(0.30)\end{array}$ & $\begin{array}{c}-0.134 * * * \\
(-2.29)\end{array}$ & $\begin{array}{c}-0.019 * * * \\
(-2.78)\end{array}$ & $\begin{array}{c}-0.3986 * * * \\
(-3.03)\end{array}$ \\
\hline$V$ & $\begin{array}{l}-0.015 \\
(-0.29)\end{array}$ & $\begin{array}{l}-0.004 \\
(-0.08)\end{array}$ & $\begin{array}{c}0.590^{* * * *} \\
(11.92)\end{array}$ & & \\
\hline TO & $\begin{array}{c}1.620 * * * \\
(6.72) \\
\end{array}$ & $\begin{array}{c}1.442 * * * \\
(5.87) \\
\end{array}$ & & & \\
\hline$I L I Q$ & $\begin{array}{c}0.444 * * * \\
(6.34)\end{array}$ & $\begin{array}{c}0.445^{* * * *} \\
(6.40)\end{array}$ & & & \\
\hline $\ln L S P$ & $\begin{array}{c}0.481 * * * \\
(5.25)\end{array}$ & $\begin{array}{c}0.484 * * * \\
(5.37) \\
\end{array}$ & & & \\
\hline$L W R$ & $\begin{array}{c}-0.181 * \\
(-1.78) \\
\end{array}$ & $\begin{array}{c}-0.177^{*} \\
(-1.70) \\
\end{array}$ & & & \\
\hline YEAR & $\begin{array}{l}-0.020 \\
(-1.07) \\
\end{array}$ & $\begin{array}{l}-0.021 \\
(-1.10) \\
\end{array}$ & & & \\
\hline $\ln S I Z E$ & & & $\begin{array}{l}-0.094 \\
(-1.35)\end{array}$ & $\begin{array}{c}-0.018 * * * \\
(-4.08)\end{array}$ & $\begin{array}{c}0.620 * * * \\
(5.92)\end{array}$ \\
\hline $\ln M K I$ & & & $\begin{array}{c}1.209 * * * \\
(3.79)\end{array}$ & $\begin{array}{c}0.032^{*} \\
(1.81)\end{array}$ & $\begin{array}{c}0.665^{*} \\
(1.65)\end{array}$ \\
\hline $\ln M K H$ & & & $\begin{array}{l}0.009 \\
(0.12)\end{array}$ & & \\
\hline $\ln O P$ & & & & $\begin{array}{c}-0.014 * * * \\
(-3.08)\end{array}$ & $\begin{array}{c}0.749 * * * \\
(7.95)\end{array}$ \\
\hline cons & $\begin{array}{c}-6.094 * * * \\
(-5.96)\end{array}$ & $\begin{array}{c}-6.052 * * * \\
(-6.02)\end{array}$ & $\begin{array}{c}-7.879 * * * \\
(-2.61)\end{array}$ & $\begin{array}{l}-0.019 \\
(-0.13)\end{array}$ & $\begin{array}{l}-4.511 \\
(-1.34)\end{array}$ \\
\hline $\mathrm{F}$ & $41.21 * * *$ & $36.54 * * *$ & $65.61 * * *$ & $5.94 * * *$ & $52.98 * * *$ \\
\hline $\mathrm{R}^{2}$ & 0.8567 & 0.8390 & 0.7809 & 0.2590 & 0.6498 \\
\hline
\end{tabular}

Notes: $*, * *$, and $* * *$ indicate statistical significance at the $10 \%, 5 \%$, and $1 \%$ levels, respectively.

Model 3 provides the result of the regression on issuing price (OP). It shows that the issue price is negatively related to underwriter ranking (REP) at the $1 \%$ statistical significance level. According to the definition of reputation, REP, the smaller the number for REP is, the higher the underwriter reputation. So, the more reputable underwriter may help boost the issue price. Therefore, the empirical result supports the second hypothesis.

Model 4 and Model 5 provide the results of the regression on underwriter fees. The regression shows that the underwriter fee is negatively correlated with underwriter ranking (REP) at the $1 \%$ statistical significance level, and empirical results do not rely on how the dependent variables are measured. The empirical result indicates that the greater the underwriter reputation, the higher the underwriting expense ratio. Thus the empirical result supports the third hypothesis. 


\section{CONCLUSIONS AND DISCUSSION}

Wilson (1975) argues that ethics is concerned with doing good, or the right thing in a given human situation. As for ethics of financial intermediaries, Chemmanur and Fulghieri (1994) argue that financial intermediaries might make "honest" mistakes legitimately, making it difficult to distinguish between intermediaries acting in good faith and those acting in their own interest, and to the detriment of investors. Reputation acquisition by intermediaries can mitigate this credibility problem. This paper has analyzed the basic business ethics problem of whether reputation acquisition forces the underwriter on the ChiNext market to do the right thing, pricing correctly under an information asymmetry environment.

\subsection{Conclusion}

Our findings highlight the fact that underwriter reputation is not well established. Under the significant information asymmetry that exists between IPO issuers and equity investors in the ChiNext market, the reputation disciplinary mechanism cannot effectively constrain an underwriter's opportunistic behavior, and the underwriter, as a financial intermediary, fails to offer third-party information certification. So, the underwriter does not work well in reducing the degree of information asymmetry between investors and issuers. The underwriters' opportunistic behavior leads to the convergence of the interest of issuers to that of underwriters. In a market where investors are chasing new issues, it is the dominant choice for inquiry investors to act in concert with the underwriters to take the high bidding price strategy to snap up IPO shares, given the inquiry mechanism where the bidders offering the high prices win. Faced with the high IPO issue price and the large extent of underpricing, the investors in the secondary market need to pay higher transaction costs. In a sense, the collusion among the underwriters, issuers and inquiry investors helps the major shareholders and investors in the primary market to seize the benefits of investors in the secondary market. For these reasons, China's securities regulatory authorities need to further reform China's IPO institution.

\subsection{Discussion}

The previous research argues that reputation represents the complex evaluation related to stakeholder expectations. Corporate reputations represent the public's cumulative judgments of firms over time, which, in turn, hinge on "relative success in fulfilling the expectations of multiple stakeholders" (Fombrun \& Shanley, 1990). But our basic conclusion shows that underwriters violate their basic ethics, pricing the securities to grab their own benefits in ChiNext IPOs. The unethical behavior imposes unfair competition on small shareholders and harms their shareholders' financial interests.

In the institutional environment where the reputation disciplinary system fails, an underwriter's behavior is distorted. Thereby, underwriters have a limited incentive to function well to improve their reputation, and grabbing their financial interest becomes the top priority. Business ethics are concerned with business practices in light of some concept of human value. In this case, the value is improving resource allocation efficiency through accurate pricing by underwriters. But underwriters fail in this field with respect to the achievement of this value.

Unethical behavior occurs at all levels in business. Financial intermediaries and the relevant professionals are part of the most important foundation of financial market. Facing a conflict of interests, unethical behavior by professionals, such as accountants, lawyers, and bankers, is a common feature (Hamilton, 2002). So, the ethical management of financial intermediaries should apply to everyday business practices, rather than be limited to the large strategic issues. Managers must also realize that ethics goes beyond the strict requirements of the law. The fair treatment of all stakeholders should be the ultimate objective of an ethical company (Fassin, 2005). Specifically, the underwriter of an IPO should treat shareholders equally whether they are big or small.

From a policy standpoint, our findings have important implications for financial regulation reforms in China. First, regulatory authorities should perfect the reputation mechanism by establishing a comprehensive ranking system that can effectively measure underwriter ethics from multiple dimensions, such as the level of IPO under-pricing, the degree of the market's recognition, etc. Second, regulators should optimize the service contract between IPO issuers and underwriters to prevent behavioral distortions. For instance, the contact could be improved 
by specifying that underwriter income should be determined mainly by their ethics ranking, but not by the total funds raised in the IPO. This incentive system will encourage underwriters to price IPO shares more accurately in order to build their reputation. At present, we should further explore IPO pricing methods to avoid collusion among IPO participants. The goal of IPO process reform in China is to vigorously promote the market-oriented offering mechanism. An inquiry pricing system is supposed to work as well as expected. However, under information asymmetry and conflicts of interest, collision undermines inquiry pricing efficiency, which seriously harms secondary market investors. We could experiment with some other forms of price discovery mechanism, such as the system of auction or fixed price-earnings ratio pricing. However, no matter what kind of pricing discovery mechanism is used, it is most important for underwriters to do the right thing.

\section{ACKNOWLEDGEMENTS}

The study was supported by the Chinese National Natural Science Foundation (Grant nos.71173166 and 71373202 ) and by the Humanities and Social Sciences research project of Department of Education of Shaanxi Province (Grant nos.2013KJ0107).

\section{AUTHOR INFORMATION}

Zuguang Wu is a Ph.D. candidate in the School of Management at Xi'an Jiaotong University, P.R. China, and a Lecturer at the department of Accountancy of Xi'an University of Technology. He has teaching experience in Financial Accounting, Taxation, and Corporate Finance. He holds memberships in the China Appraisal Society and China Association of Consulting Engineers. His main research fields are corporate governance, corporate finance, and corporate ethics, and he is currently leading a research project (No. 2013KJ0107) funded by the Department of Education of Shaanxi Province, China. E-mail: zgw@xaut.edu.cn (Corresponding author)

Difang Wan is a professor in the School of Management at Xi'an Jiaotong University, P.R. China. His main research interests include corporate governance, corporate finance and financial markets, and he is currently leading research projects (No. 71173166 and No.71373202) funded by National Natural Science Foundation of China. E-mail: $\underline{\text { dfwan@mail.xjtu.edu.cn }}$

\section{REFERENCES}

1. Benveniste, L. M., Busaba, W. Y., \& Wilhelm, W. J. (2002). Information externalities and the role of underwriters in primary equity markets. Journal of Financial Intermediation, 11, 61-86.

2. Beatty R. P, Bunsis, H., Hand, J. R.M. (1998). The indirect economic penalties in SEC investigations of underwriters. Journal of Financial Economics, 50(2), 151-186.

3. Beatty, R. P., \& Ritter, J. R. (1986). Investment banking, reputation, and the underpricing of initial public offerings. Journal of Financial Economics, 15(2), 213-232.

4. Carter, R. B., \& Dark, F. H., \& Singh, A. K. (1998). Undewriter reputation, initial return and long-run performance of IPO stocks. The Journal of Finance, 53(1), 285-311.

5. Chemmanur. T. J., \& Fulghieri, P. (1994). Investment bank reputation, information production, and financial intermediation. The Journal of Finance, 49, 57-79.

6. $\quad$ Crane, A., \& Matten, D. (2004). Business Ethics. Oxford University Press.

7. Dunbar, C. G. (2000). Factors affecting investment bank initial public offerings market share. Journal of Financial Economics, 55, 3-41.

8. Fassin, Y. (2000). Innovation and ethics, ethical considerations in the innovation business. Journal of Business Ethics, 27, 193-203.

9. Fassin, Y. (2005). The reasons behind non-ethical behavior in business and entrepreneurship. Journal of Business Ethics, 60, 265-279.

10. Fombrun, C., \& Shanley, M. (1990). What's in a name? Reputation building and corporate strategy. Academy of Management Journal, 33, 233-258.

11. Freeman, R. E. (1984). Strategic management, A stakeholder's approach. Boston: Pitman.

12. Guo, H., \& Zhao, Z. (2006). An empirical research of the impact of underwriters reputation on the IPO's pricing, the initial and long-term return. Management World, 3, 122-128. 
13. Hamilton, A. M. (2002). A season of scandal. Stanford Business, 11, 14-18.

14. Kirkulak, B., \& Davis, C. (2005). Underwriter reputation and underpricing: Evidence from the Japanese IPOs market. Pacific-Basin Financial Journal, 13(4), 451-470.

15. McDonald, J. G., \& Fisher, A. K. (1972). New-issue stock price behavior. The Journal of Finance, 27, 97102.

16. Megginson, W., \& Weiss, K. (1991). Venture capitalist certification in initial public offerings. Journal of Finance, 46, 879-903.

17. Song, W. L. (2004). The impact of clients' alleged financial reporting fraud on underwriter reputation. (Working Paper). pp. 1-41. Retrieved from http://www.ssrn.com.

18. Tinic, S. M. (1998). Anatomy of initial public offerings of common stock. The Journal of Finance, 43, 789822.

19. Wang, H., He, J., \& Zhang, Z. (2006). An empirical study on the relationship between quotation and underwriting risk. Journal of Financial Research, 311, 61-69.

20. Wilson, J. A. (1975). Morality and the contemporary business system. Journal of Contemporary Business, 4, 31-58. 